\title{
Enhanced antioxidant activity of okara through solid state fermentation of GRAS Fungi
}

\author{
Azis Boing SITANGGANG ${ }^{1,2,3 *}$ (D), Wenny Silvia Loren SINAGA ${ }^{4}$, Felicia WIE ${ }^{4}$, Franz FERNANDO ${ }^{4}$, \\ Warawut KRUSONG ${ }^{3}$
}

\begin{abstract}
The enhancement of antioxidant activity of fermented okara was investigated using fungal solid-state fermentation. The initial fungal concentration and water activity were found to influence the enhanced antioxidant capacity of fermented okara. Extracellular enzymes, especially proteases and carbohydrases might facilitate the hydrolysis of okara protein that yielded antioxidative amino acids and peptides, as well as the release of isoflavones-derived components. Fermentation of okara with $R$. oligosporus with $1.04 \times 10^{-3} \mathrm{~g}_{\mathrm{DCW}} / \mathrm{g}_{\text {okara }}$ as initial concentration, water activity of 0.931 was found to yield the highest antioxidant strength. Whereas for $A$. Oryzae, $1.6 \times 10^{-3} \mathrm{~g}_{\mathrm{DCw}} / \mathrm{g}_{\text {okara }}$ was optimum as the initial concentration with water activity of 0.913 . With these optimum conditions, solid-state fermentation of okara could enhance the antioxidant activity up to 2.6- and 5.5-fold, respectively for $R$. oligosporus and A. oryzae. Besides having an enhanced antioxidant activity, the fermented okara also had higher protein content, amino nitrogen content, and protein digestibility.
\end{abstract}

Keywords: antioxidant; A. oryzae; okara; R. oligosporus; solid-state fermentation.

Practical Application: Fermentation conditions within this study can be used as a strategy to valorise okara.

\section{Introduction}

Okara is a by-product from soymilk or tofu production, and usually used as feed stocks, fertilizer, or directly discarded as waste (Li et al., 2012). For the latter, large quantities of okara produced per annum will lead to environmental problems (O’Toole, 1999). It is, in fact contradicted to inherent nutrients which are rich in okara. In okara, especially protein and its respective amino acids, can level up to $27 \%$ based on the dry basis (Rashad et al., 2011). Considering this, there are many strategies have been reported on the valorisation of okara for human consumption, such as increasing its digestibility through treatments with cellulolytic and proteolytic enzymes (Kasai et al., 2004), protein deamination (Chan \& Ma, 1999), or liberation of its phenolic content, and other enhancement of its nutritive values through fermentations (Hur et al., 2014).

Microbial fermentation has been reported to influence the antioxidant activity in plant-based foods. During fermentation, phenolic compounds can be hydrolysed that entails on the depolymerisation of its complex, and liberation of its derivatives (Hur et al., 2014). Additionally, due to the production of extracellular proteases, and carbohydrases, both protein and carbohydrate complex within the structures of cereals or grains are hydrolyzed. Either liberation of phenolic compounds or the production of small molecular peptides will consequently lead to a higher radical scavenging activity of the fermented cereal/grains (Chang et al., 2009).
Compared to submerged fermentation, solid state fermentation offers several advantages, as it is more cost- and energy-effective, as well as environmentally friendly (Krishna, 2005). Commonly, solid state fermentation is used to enhance the nutritional value of cereal grains in which microbial proteases are expected to hydrolyze the proteins inherently found in the beans or grains (Barampama \& Simard, 1995). For instance, the hydrolysis of proteins in soybean during tempe fermentation usually yields small molecular weight peptides and free amino acids which are active biologically (Nout \& Kiers, 2005). Especially for okara, its solid state fermentations using various microorganisms (i.e., bacteria and fungi) have been reported (Chi \& Cho, 2016; Mateos-Aparicio et al., 2010; Visessanguan et al., 2005). Most of the goals are to enhance okara's antioxidant properties, flavour properties, protein digestibility, production of antibiotic, etc. (Guan et al., 2016; Ohno et al., 1996; Vong et al., 2018).

Within this work, a detailed comparative study between Rhizopus oligosporus- and Aspergillus oryzae-based okara solid state fermentation is reported. $R$. oligosporus is a common mold used in Indonesia for tempe fermentation, and is known to have a proteolytic activity. According to Wronkowska et al. (2015), solid state fermentation using $R$. oligosporus could enhance the antioxidant properties of raw and roasted buckwheat groats in terms of free radical scavenging activity. The study conducted by Vong et al. (2018) on the utilization of R. Oligosporus for okara solid state fermentation was not specific. The enhancement of okara properties by $R$. Oligosporus was not singled out within 
their study, as they mainly discussed the detailed possible synergistic effects between R. oligosporus and Yarrowia lipolytica in producing enzymes for biocoversion some components in the okara cell wall. On the other hand, there have been many biomodifications using $A$. oryzae reported, and one of them was for the improvement of digestibility of the fermented grains or cereals (Teng et al., 2012). De Castro \& Sato (2014) reported that culturing $A$. oryzae on different agroindustrial wastes as matrix supports yield high protease activity.

The use of individual $R$. oligosporus and A. oryzae are expected to produce extracellular protease(s) and also possible carbohydrases that concomitantly hydrolyze the proteins in okara into bioactive peptides, and the intact complex carbohydrates to release the proteins itself. For fungal protease, its production has been reported to be influenced by the fermentation time, incubation temperature, initial mold concentration, and water activity $\left(a_{w}\right)$ (Nuñez-Gaona et al., 2010). Thus, these factors must be considered while conducting solid state fermentation of okara. Additionally, besides having generally recognized as safe (GRAS) status, the two fungi are also grouped as "microbial food cultures" (MFC) based on three criteria, such as: regulatory systems and legal terms, scientific criteria, and inventory of microbial species in food fermentations (Bourdichon et al., 2012). Therefore, the utilization of these fungi to enhance the functional properties of okara intended for functional food applications will be appropriate.

\section{Materials and methods}

\subsection{Materials}

Okara, tempe and tofu were purchased from a local market in Tangerang, Indonesia. Especially for okara, it is a solid waste of soymilk production. Pure culture of R. oligosporus and A. oryzae were purchased from MBRIO Biotekindo, Bogor, Indonesia. Potato dextrose broth (PDB, P6685) was from Sigma-Aldrich, Thailand. For ascorbic acid (100468), 2,2-diphenyl-1-picrylhydrazyl solution (300267), sodium hydroxide, phenolphthalein (107233), hydrogen peroxide (107298), boric acid (100158), bromocresol green-methyl red indicator (108121), pepsin (107185), trichloroacetic acid (100810), pancreatin (107133), formaldehyde (104003), and sodium azide (106687) were purchased from Merck Millipore, Thailand. For methanol, hydrogen chloride, sodium hydroxide, phosphate buffer ( $\mathrm{pH} \mathrm{8)}$, sulfuric acid, and ethanol were analytical grade and purchased from PT. Smart Lab, Indonesia.

\subsection{Growth profile of $R$. oligosporus and A. oryzae}

Initially, the lyophilized fungal cultures were thawed in a water bath at $30^{\circ} \mathrm{C}$. The thawed $R$. oligosporus and A. oryzae culture were looped into sterilized PDB (temperature of $121^{\circ} \mathrm{C}$, pressure of $1 \mathrm{~atm}$ for $1 \mathrm{~h}$ ). The inoculated broth with individual fungal type was incubated for 3-5 d at temperature of $30^{\circ} \mathrm{C}$. A $10 \mu \mathrm{L}$ of solution from each newly activated fungus was placed into a clean test tube where fresh PDB solution was added into, until $10 \mathrm{~mL}$ of total solution was obtained. Another incubation period was performed until $11 \mathrm{~d}$ at different temperatures $\left(25,30\right.$, and $\left.37^{\circ} \mathrm{C}\right)$. The growth profile was constructed for each type of fungus by monitoring the amount of biomass produced (expressed in gram dry cell weight, $\mathrm{g}_{\mathrm{DCW}}$ ).

\subsection{Effect of initial fungal concentration and water activity on the functional properties of okara}

A $10 \mathrm{~g}$ of dried okara (see Table 1 for dried okara properties) was placed into petri dishes (P5606 Sigma-Aldrich), and added with $10 \mathrm{~mL}$ of distilled water to reach the water activity, $a_{w}$ of 0.913. Different initial concentrations ( $\mathrm{g}_{\mathrm{DCw}}$ ) of $R$. oligosporus and $A$. Oryzae were inoculated separately into the substrates. The incubations were carried out for $5 \mathrm{~d}$, by placing the petri dishes into an incubator at predetermined temperature. For investigating the influence of water activity, the dried okara (moisture content of $8.26 \% \mathrm{wb}$ ) was added with sterile water to vary the $a_{w}$ level.

\subsection{Radical scavenging activity}

A $2.0 \mathrm{~mL}$ of methanol extract (i.e., okara, fermented okara, tofu or tempe) or standard (i.e., ascorbic acid) at a concentration of $2.0 \mathrm{mg} / \mathrm{mL}$ was added to $1.0 \mathrm{~mL}$ of $0.3 \mathrm{mM}$ 2,2-diphenyl-1-picrylhydrazyl solution (DPPH). The solution was mixed thoroughly and left in the dark to stand for $30 \mathrm{~min}$ at $30^{\circ} \mathrm{C}$. The blank for each sample was prepared by replacing DPPH with methanol in the prementioned mixture above. The control preparation was made with $1.0 \mathrm{~mL}$ of methanolic DPPH plus $2.0 \mathrm{~mL}$ of methanol (Rashad et al., 2011). The absorbance of each solution was determined at $517 \mathrm{~nm}$. The radical scavenging activity, RSA (\%) was calculated as follows (equation 1):

$R S A(\%)=\left(1-\frac{A_{s}}{A_{c}}\right) \times 100 \%$

where RSA (\%) stands for radical scavenging activity, $A_{s}$ and $A_{c}$ refer to absorbance of sample and control, respectively (-).

\subsection{Protein content}

The protein determination following Kjeldahl method (Association of Official Analytical Chemists, 2005) was started by weighing $1.0 \mathrm{~g}$ of okara, $7.0 \mathrm{~g}$ of $\mathrm{K}_{2} \mathrm{SO}_{4}, 5.0 \mathrm{mg}$ of selenium, $10 \mathrm{~mL}$ of $\mathrm{H}_{2} \mathrm{SO}_{4}$, and $10 \mathrm{~mL}$ of $\mathrm{H}_{2} \mathrm{O}_{2}$ into $100 \mathrm{~mL}$ Kjeldahl flask. The mixture was then boiled at $420^{\circ} \mathrm{C}$ for $30 \mathrm{~min}$. The end-point of the process was indicated by a clear solution without leaving charred materials. The solution was cooled down to $50-60{ }^{\circ} \mathrm{C}$, followed by the addition of $50 \mathrm{~mL}$ of distilled water. A $50 \mathrm{~mL}$ of $35 \% \mathrm{NaOH}$ was added to the mixture, and the distillation was performed to obtain approximately $100 \mathrm{~mL}$ of distillate.

Table 1. Characteristics of dried okara.

\begin{tabular}{lc}
\hline \multicolumn{1}{c}{ Okara Characteristics } & Values \\
\hline Moisture content $[\% \mathrm{wb}]$ & $8.26 \pm 0.24$ \\
Water activity $a_{w}[-]$ & 0.183 \\
Particle size $[\mu \mathrm{m}]$ & $6.15 \times 10^{-1}$ \\
Radical scavenging act. [\%] & $14.87 \pm 0.44$ \\
Protein content $[\% \mathrm{db}]$ & $23.96 \pm 0.43$ \\
Amino Nitrogen content $[\mathrm{mg} / \mathrm{g}]$ & $3.48 \pm 0.12$ \\
\hline
\end{tabular}


This distillate was placed into a $125 \mathrm{~mL}$ Erlenmeyer flask that previously poured with $25 \mathrm{~mL}$ of $4 \%$ boric acid. Afterwards, about 2-3 drops of bromocresol green-methyl red indicator were added, and this final solution was titrated with $0.2 \mathrm{~N} \mathrm{HCl} \mathrm{until}$ faint pink gray color was obtained. The nitrogen and protein content were calculated as follows (equation 2 and equation 3 ):

$N(\%)=\left(\frac{\left(V_{H C l}-V_{\text {blank }}\right) \times N \times 14.007}{W_{\text {sample }}}\right) \times 100 \%$

$P(\%)=N(\%) \times C_{\text {fact }}$

where $N(\%)=$ percentage of nitrogen in the sample, $N=$ Normality (eq/L), $V=$ volume $(\mathrm{mL}), W=$ weight $(\mathrm{g}), P(\%)=$ percentage of protein in the sample, and $C_{\text {fact }}=$ conversion factor of nitrogen to protein, and in this study the value used was 5.71.

\subsection{Amino nitrogen content and degree of hydrolysis}

Formol titration was used to determine the amino nitrogen content of okara (Morais et al., 2013). Formaldehyde reagent was prepared by diluting $25 \mathrm{~mL}$ of formaldehyde with a $50 \%$ ethanol to reach a volume of $250 \mathrm{~mL}$. The $\mathrm{pH}$ of this reagent was brought to 8.0 with $0.005 \mathrm{M} \mathrm{NaOH}$. The okara hydrolysate solution was prepared where the $\mathrm{pH}$ was also adjusted to reach 8.0. About 5.0 $\mathrm{mL}$ of formaldehyde reagent and $5.0 \mathrm{~mL}$ sample solution were poured into the Erlenmeyer flask, continued by the addition of 2-3 drops of phenolphthalein. The final solution was titrated with $0.005 \mathrm{M} \mathrm{NaOH}$ until pink colored solution was obtained. The total volume of $\mathrm{NaOH}$ consumed was recorded, and the amino nitrogen content was calculated as follows (equation 4):

$$
\text { Am.N }\left(\mathrm{mg} / \mathrm{g}_{\text {sample }}\right)=V_{\mathrm{NaOH}} \times M_{\mathrm{NaOH}} \times 14 \mathrm{mg} / \mathrm{mmol} \times \mathrm{DF}
$$

where $A m \cdot N=$ amino nitrogen content $\left(\mathrm{mg} / \mathrm{g}_{\text {sample }}\right), V=$ volume (mL), $M=$ Molarity, and $D F=$ dilution factor.

The degree of hydrolysis was calculated as the ratio of amino nitrogen content $(A m . N)$ from formol titration and total nitrogen $(N)$ from Kjeldahl method as following (equation 5):

$$
D H(\%)=\left(\frac{A m . N}{N}\right) \times 100 \%
$$

where $D H=$ degree of analysis (\%).

\subsection{In vitro protein digestibility}

The samples were weighed for $250 \mathrm{mg}$ and transferred into $50 \mathrm{~mL}$ Erlenmeyer flask, whereas for the blank about $250 \mu \mathrm{L}$ of deionized water were used. A $15 \mathrm{~mL}$ of $0.1 \mathrm{~N} \mathrm{HCl}$ containing $1.5 \mathrm{mg} / \mathrm{mL}$ pepsin was added into each flask, and then incubated at $37^{\circ} \mathrm{C}$ for $3 \mathrm{~h}$. The reaction was stopped by neutralizing the solution with $7.5 \mathrm{~mL}$ of $0.5 \mathrm{~N} \mathrm{NaOH}$. For the pancreatic digestion, it was done overnight at $37^{\circ} \mathrm{C}$ in which $10 \mathrm{~mL}$ of $0.2 \mathrm{M}$ phosphate buffer ( $\mathrm{pH} 8$ ) containing $10 \mathrm{mg}$ of pancreatin (107133, Merck-Millipore) was added to the neutralized solution. Additionally, $1.0 \mathrm{~mL}$ of $0.005 \mathrm{M}$ azide was also added to the mixture to prevent microbial growth. Prior to centrifugation at
$503 \times \mathrm{g}$ for $20 \mathrm{~min}$, the mixture was added with $1.0 \mathrm{~mL}$ of $0.6 \mathrm{M}$ trichloroacetic acid (Akeson \& Stahmann, 1964; Almeida et al., 2015). The protein content was determined based on nitrogen content using Kjeldahl method (Association of Official Analytical Chemists, 2005). The in vitro protein digestibility was calculated as follows (equation 6):

$\operatorname{Dig}(\%)=\left(1-\frac{N_{b}}{N_{s}}\right) \times 100 \%$

where $\operatorname{Dig}=$ protein digestibility $(\%), N_{b}=$ nitrogen content in blank $\left(\mathrm{mg} / \mathrm{g}_{\text {sample }}\right), N_{s}=$ nitrogen content in sample $\left(\mathrm{mg} / \mathrm{g}_{\text {sample }}\right)$.

\subsection{The amino acids analysis}

The analysis of amino acids was performed by PT. Saraswanti Indo Genetech (18-5-17/MU SMM-SIG, UPLC) where the method has been also reported by Alen et al. (2017). The hydrolysis of dried okara and fermented okara was done at $110^{\circ} \mathrm{C}$ for $24 \mathrm{~h}$ using $6 \mathrm{M} \mathrm{HCL}$ containing $0.5 \%(\mathrm{w} / \mathrm{v})$ phenol. After the hydrolysis, the samples were dried using $20 \mathrm{~mL}$ of ethanol: triethylamine: water $(2: 1: 2, \mathrm{v} / \mathrm{v})$ for $20 \mathrm{~min}$ at room temperature. Prior to analysis, the sample was dissolved in $100 \mu \mathrm{L}$ of equilibration buffer. The analysis of the amino acids was performed with a Waters C18 column $(3.9 \times 150 \mathrm{~mm})$. The used mobile phase was a combination between acetonitrile and sodium acetate buffer (about $300 \mathrm{~mL}$ acetonitrile, $200 \mathrm{~mL}$ water, $0.2 \mathrm{~mL}$ CaEDTA). A $20 \mu \mathrm{L}$ of aliquots was injected into the column, and the measurement was performed at $254 \mathrm{~nm}$. The comparison was made between the individual peaks of the sample with the standards (Alen et al., 2017).

\section{Results and discussion}

\subsection{Okara characteristics}

The initial characteristics of the dried okara are shown in Table 1. Prior to be used, the dried okara was milled and sieved through 60 mesh. The particle size obtained was about $6.146 \times 10^{-1} \mu \mathrm{m}$. The initial antioxidant activity of the dried okara, in terms of radical scavenging activity was $14.87 \pm 0.44 \%$. Presumably, the presence of isoflavones was associated to this antioxidant strength. It must be noted that the okara used was a solid waste of soy milk production. Due to the application of wet milling process for the preparation of soy milk, the soybean proteins were extracted. In this study, the protein content of okara was about $24 \%$ which was far below from its initial content in soybean meal, ranging from $37-42 \%$ (O'Keefe et al., 2015). This value was comparable to that reported by Yokomizo et al. (2002) and Li et al. (2012), where the concentrations of okara protein in their studies were 25 , and $25.4-28.4 \% \mathrm{db}$, respectively.

\subsection{The growth curve of R. oligosphorus and A. oryzae}

Different cell concentrations were obtained as the incubation temperature was varied respective to incubation time for both R. oligosporus and A. oryzae. The incubation temperature of $30^{\circ} \mathrm{C}$ yielded the highest biomas concentration for both fungi (data for 25 and $37^{\circ} \mathrm{C}$ are not shown). R. oligosporus and A. oryzae are known to be mesophilic fungi. Therefore, both fungi are 
able to grow at moderate temperatures between 20 and $45^{\circ} \mathrm{C}$, and with optimum growth temperatures between 30 and $39^{\circ} \mathrm{C}$ (Schiraldi \& Rosa, 2014).

The optimum productions of an extracellular enzyme is normally associated with the optimum cell concentration obtained throughout the incubation time. According to Rauf et al. (2010), temperature of $30^{\circ} \mathrm{C}$ was the optimum growth temperature for acidic protease production from $R$. oligosporus through solid state fermentation of sunflower meal. Whereas for A. oryzae, temperatures of $28-30{ }^{\circ} \mathrm{C}$ were found to be the suited range for production protease, amylase and glucoamylase (Puri et al., 2013; Kamath et al., 2010). Within this study, temperature of $30^{\circ} \mathrm{C}$ was confirmed and selected as the incubation temperature for both fungal preparations, and okara solid-sate fermentation.

At the first four-day of incubation at $30^{\circ} \mathrm{C}$, both $R$. oligosporus and $A$. oryzae had a growth rate that was relatively similar. $R$. oligosporus had a maximum biomass concentration of

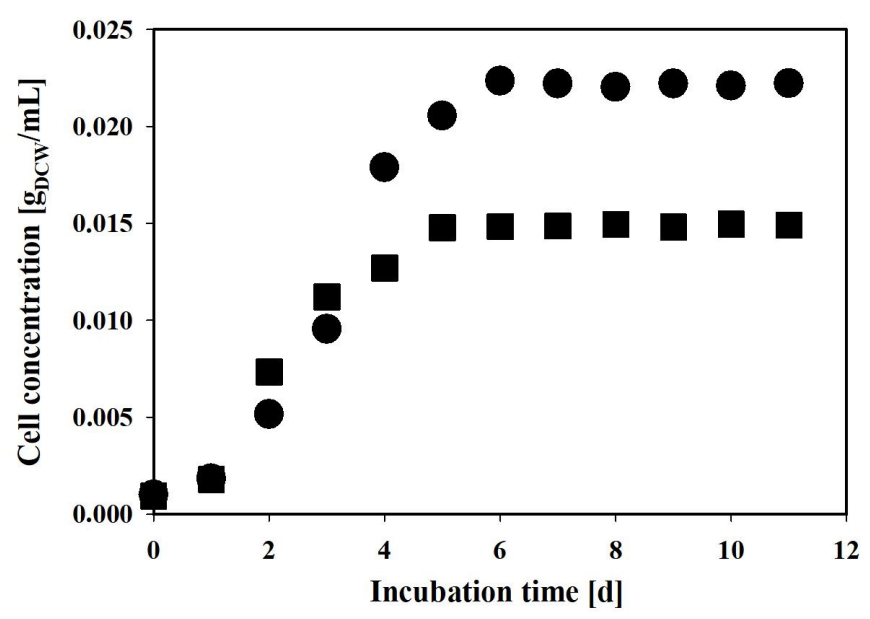

Figure 1. The growth curve of R. oligosphorus and A. oryzae in PDB medium, incubated at $30^{\circ} \mathrm{C}$.
$22.34 \times 10^{-3} \mathrm{~g}_{\mathrm{DCW}} / \mathrm{mL}$ at $6 \mathrm{~d}$ incubation. Whereas for A. Oryzae, it was obtained at $5 \mathrm{~d}$ incubation, where the value was lower approximately $34 \%$ compared to $R$. Oligosporus biomass concentration (Figure 1).

\subsection{Effect of initial fungal concentration on okara properties}

Within this study, three levels of initial biomass concentration for each fungus were designed to conduct solid state fermentations of okara. These levels of fungal concentration were obtained by following the growth profile of each fungus that previously described. Unfortunately, the levels of the concentration were not the same for both fungi. Definitely, such a simple dilution could be performed to obtained the same levels. However, one must carefully consider to have an identical substrate's water activity for both fungi.

With the highest initial $R$. oligosporus concentration (i.e., $2.44 \times 10^{-3} \mathrm{~g}_{\mathrm{DCW}} / \mathrm{g}_{\mathrm{okara}}$ ), the highest radical scavanging activity was obtained after for $4 \mathrm{~d}$ incubation (32.33\%) (Figure 2a). At cell concentration of $1.95 \times 10^{-3} \mathrm{~g}_{\mathrm{DCW}} / \mathrm{g}_{\text {okara }}$, the antioxidant acitivity also peaked at $4 \mathrm{~d}$ incubation. However, the value was smaller than that of the highest initial $R$. oligosporus concentration. The okara fermentation with the lowest initial concentration of R. oligosporus yielded the highest antioxidant activity of $40.1 \%$ after $5 \mathrm{~d}$ fermentation.

Okara fermentation with $A$. oryzae could obtain the highest antioxidant activity of $82.6 \%$ using the highest initial biomass concentration (i.e., $1.6 \times 10^{-3} \mathrm{~g}_{\mathrm{DCw}} / \mathrm{g}_{\mathrm{okara}}$ ). This was achieved for $4 \mathrm{~d}$ incubation period (Figure $2 \mathrm{~b}$ ). For the other two initial biomass concentrations of $A$. oryzae, the highest antioxidant activity also peaked at $4 \mathrm{~d}$ incubation, around 76 and $78 \%$, respectively for cell concentration of $0.8 \times 10^{-3}$ and $1.4 \times 10^{-3} \mathrm{~g}_{\mathrm{DCW}} / \mathrm{g}_{\mathrm{okara}}$. It was found that solid state fermentation of okara using $R$. oligosporus and $A$. oryzae could enhance the antioxidant activity up to 2.6- and 5.5-fold, respectively.
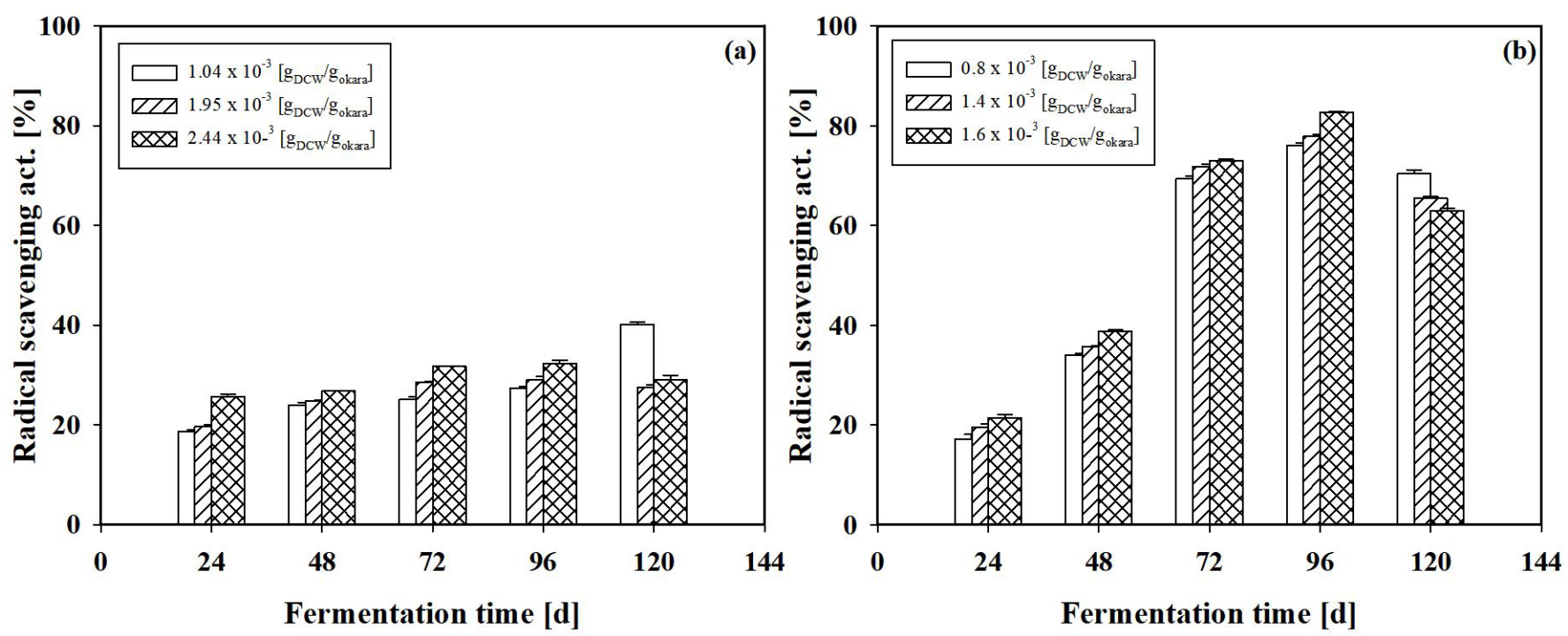

Figure 2. Influence of (a) R. oligosporus and (b) A. oryzae initial concentrations towards antioxidant activity of fermented okara, incubated at $30^{\circ} \mathrm{C}$, and water activity $\left(a_{w}\right)$ of 0.913 . 
The increase of antioxidant activity of fermented okara has been also reported in many studies utilizing different microorganisms. Rashad et al. (2011) mentioned that the highest significant levels of antioxidant activities of fermented okara were achieved with solid state fermentation of $K$. marxianus NRRL Y-8281. It was assumed that fungal extracellular $\beta$-glucosidase produced during fermentation could catalyse the release of aglycones from okara. Additionally, high concentrations of genistein and daidzein were reported during tempe fermentation which was caused by the activity of $R$. oligospous $\beta$-glucosidase on isoflavones (Murakami et al., 1984).

Besides isoflavones, peptides and amino acids might also play a vital role for the increase of scavenging activity of fermented okara. Yokomizo et al., (2002) demonstrated that fungal and bacterial proteases are able to hydrolyse okara protein to have antioxidative activity-based peptides against the peroxidation of linoleic acid performed in an aqueous system at $\mathrm{pH}$ 7.0. Four antioxidative peptides were successfully isolated from the hydrolysate prepared with the addition of B. substilus protease (Yokomizo et al., 2002). Related to this work, Sparringa \& Owens (1999) reported that after $3 \mathrm{~d}$ fermentation, approximately eight-fold increase in amino acids and peptides content of tempe was pronounced.

Vong et al. (2018) reported the coculture of R. oligosporus and yeast Yarrowia lipolytica (ROYL) on okara. After fermentation, the flavor, digestibility as well as nutritional value of okara were enhanced. The enhancements that are specifically related to the increased antioxidant activities were $254 \%$ more free amino acids, $179 \%$ more isoflavone aglycones and $197 \%$ more free phenolic acids. Moreover, Guan et al. (2016) used Actinomucor elegans DCY-1 to ferment okara. They assumed that proteins were hydrolyzed into peptides during fermentation. Thus, fermented okara showed an increase in antioxidant activities as indicated by the enhanced ferrous ion-chelating activity, reducing power and scavenging effect of ABTS, DPPH and hydroxyl radicals of fermented okara. Within this study, it conclusively considered that release of isoflavones-derived compounds, small molecular weight peptides, and amino acids produced during the fermentation could enhance the antioxidant activities of fermented okara.

In Figure $3 \mathrm{a}$ and $\mathrm{b}$, $\mathrm{a}$ combination of a longer fermentation time and a higher initial biomass concentration was able to yield a higher degree of protein hydrolysis. Okara fermentation that was conducted for $5 \mathrm{~d}$ at the highest initial cell concentration for both fungi yielded the highest degree of hydrolysis, of 19.2 and $26.3 \%$, respectively for $R$. oligosporus and $A$. oryzae. The difference of the degree of hydrolysis between $R$. oligosporus and $A$. oryzae might be related to the amount of protease produced and its corresponding activity (Teng et al., 2012).

According to Zhang et al. (2014), the formation of free amino acids was linear to amino nitrogen, and increased proportionally to the length of fermentation. A longer fermentation was considered to give sufficient time for the accumulated extracellular protease to hydrolyze protein into oligopeptides, small molecular weight peptides and even into free amino acids (Zhang et al., 2014). According to Zou et al. (2016), most of peptides that have antioxidant activity are in the range of tripeptides until oligopeptides. Adebiyi et al. (2009) mentioned that antioxidative peptides normally have molecular weights between 600 until 2,000 Da. Hence, the degree of hydrolysis might be able to explain the reduction of antioxidant activity in Figure $2 \mathrm{a}$ and $\mathrm{b}$ after a prolonged fermentation. After the highest antioxidant activity was obtained in fermented okara, such prolonged fermentation would facilitate further hydrolysis of oligopeptides and small molecular peptides into free amino acids that entailed in a less antioxidant strength.

\subsection{Effect of water activity on okara properties}

It is necessary to determine the optimum water activity in solid-state fermentation. A lower water activity in the fermentation system causes solubility problems of nutrients found in the substrate. On the other hand, high water activity, i.e., higher
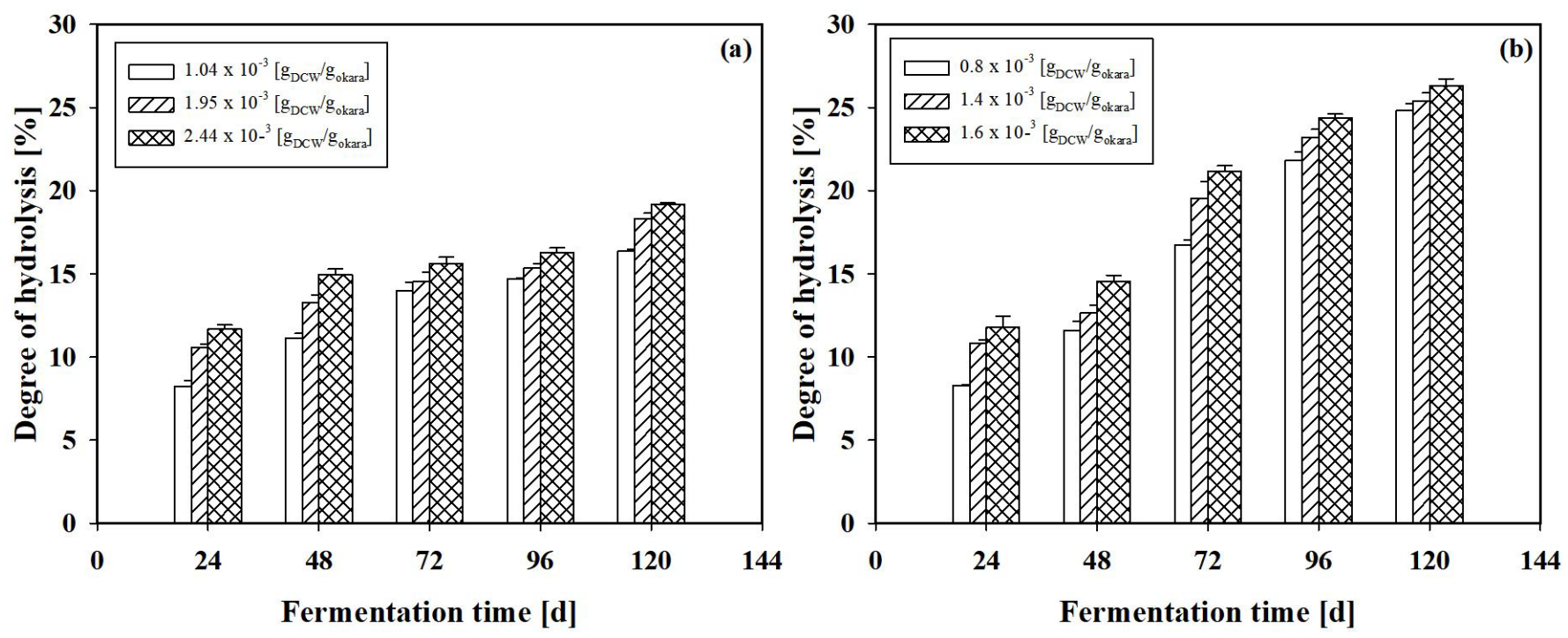

Figure 3. Influence of (a) R. oligosporus and (b) A. oryzae initial concentrations towards degree of protein hydrolysis of fermented okara, incubated at $30^{\circ} \mathrm{C}$, and water activity $\left(a_{w}\right)$ of 0.913 . 
moisture level can lead to a reduced porosity of the substrate, and thereby limiting oxygen transfer (Prasad \& Raju, 2013). In Figure $4 \mathrm{a}$ and $\mathrm{b}$, the increase of water activity resulted in a higher antioxidant capacity and protein degree of hydrolysis of R. oligosphorus-based okara solid state fermentation. However, for A. oryzae-based okara solid state fermentation, an increase in water activity yielded a lower value either for antioxidant activity or degree of hydrolysis. Higher water activity in A. oryzae-based okara solid state fermentation might result in tight mass that restricted the aeration, decreased porosity, and the available area for growth as well (Yu et al., 2012).

\subsection{Amino acid profiles of fermented okara}

The comparison of amino acids profile between unfermented and fermented okara can be seen in Figure 5. The respective amino acids that have been reported to have antioxidant activity are proline, histidine, tyrosine, cysteine, valine, leucine, phenylalanine, and tryptophan (Hur et al., 2014). Cysteine and tyrosine were increased in A.oryzae-based okara fermentation, while for R. oligosporus-based okara fermentation only showed an increase in cysteine. Moreover, essential amino acids such as methionine, cysteine, tryptophan, and threonine were increased
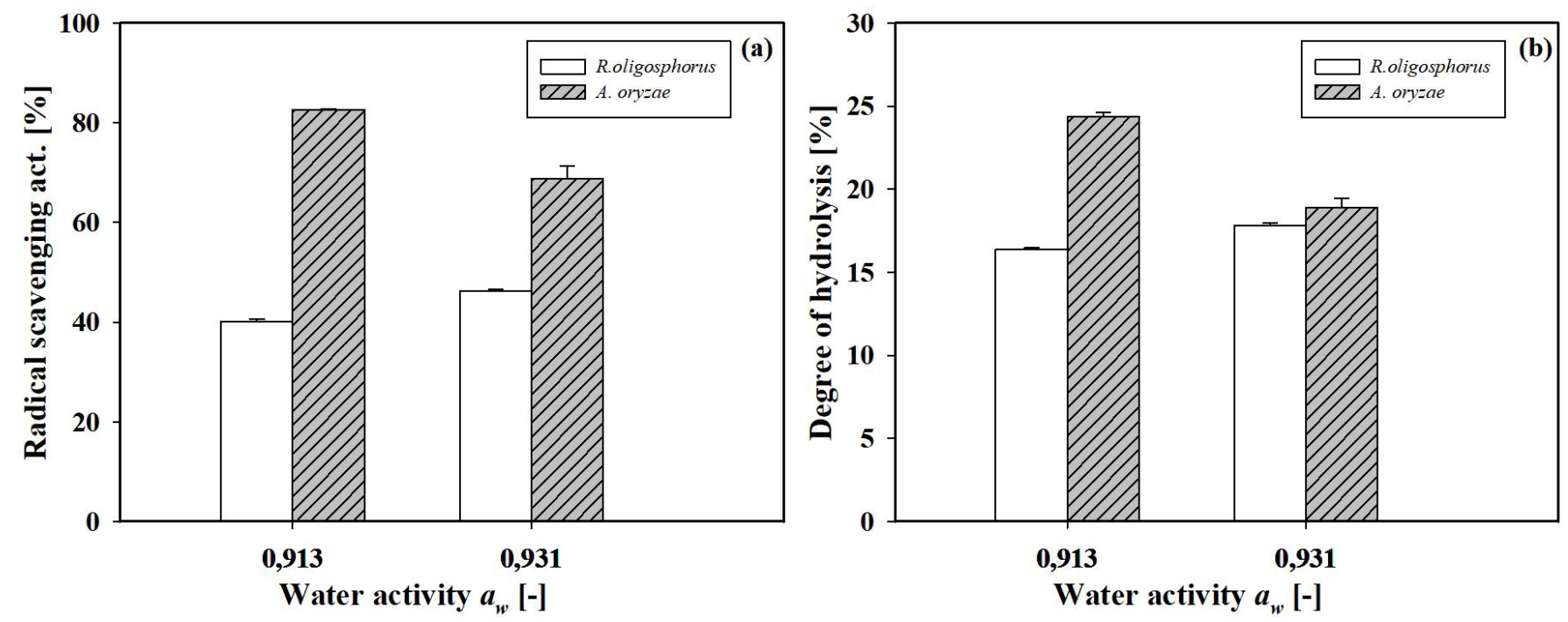

Figure 4. Influence of water activity $a_{w}$ on the degree of protein hydrolysis (a) and antioxidant activity (b) of fermented okara. Conditions: for R. oligosphorus-based okara fermentation, the initial concentration was $1.04 \times 10^{-3} \mathrm{~g}_{\mathrm{DCw}} / \mathrm{g}_{\text {okara }}$, incubated at $30^{\circ} \mathrm{C}$ for $5 \mathrm{~d}$, whereas for A. oryzae-based okara fermentation, the initial concentration was $1.6 \times 10^{-3} \mathrm{~g}_{\mathrm{DCW}} / \mathrm{g}_{\text {okara }}$, incubated at $30^{\circ} \mathrm{C}$ for $4 \mathrm{~d}$.

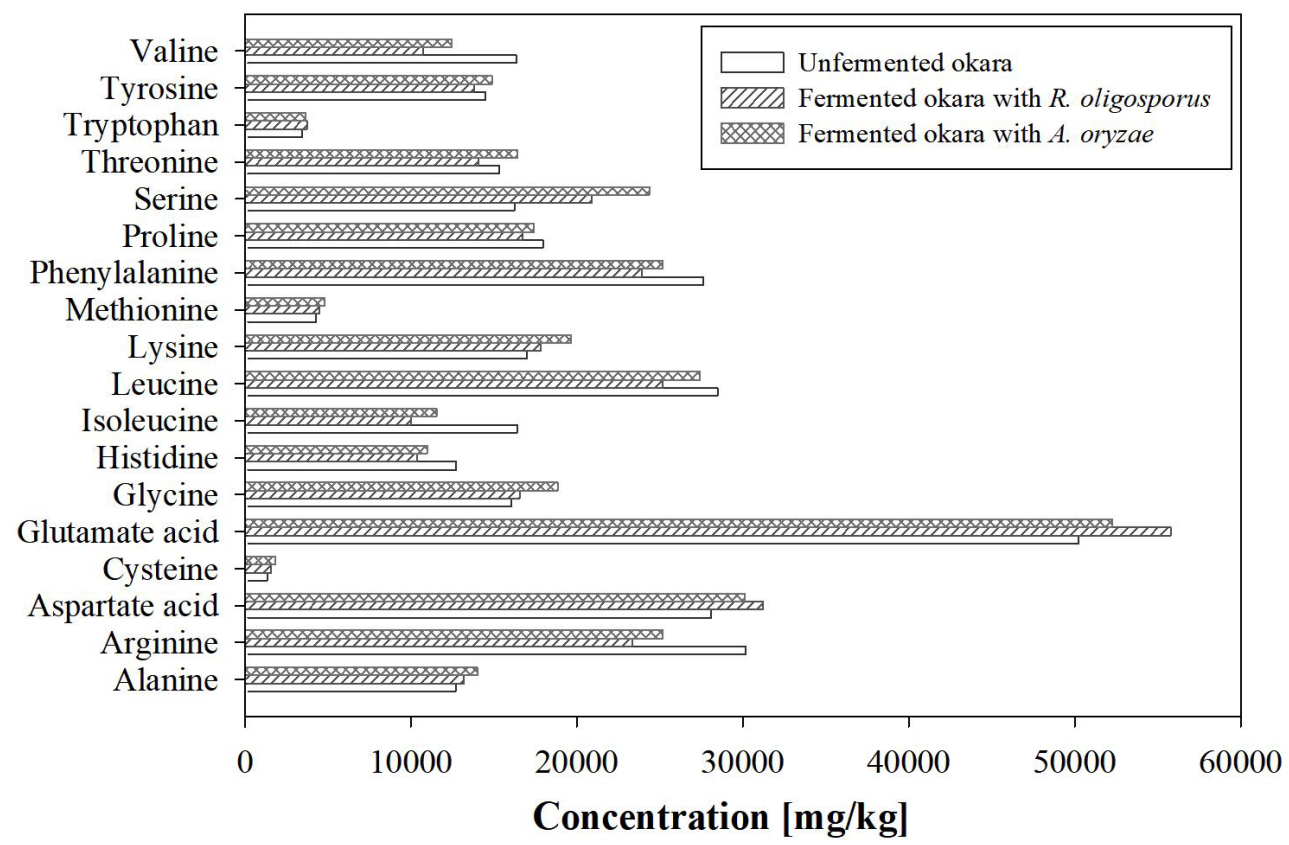

Figure 5. Amino acid profiles of unfermented and fermented okara with R. oligosporus and A. oryzae. 
Table 2. Functional comparison between unfermented, fermented okara, and other soy-based products.

\begin{tabular}{lccccc}
\hline & $\begin{array}{c}\text { Radical scavenging } \\
\text { act. [\%] }\end{array}$ & $\begin{array}{c}\text { Protein } \\
{[\% \mathrm{db}]}\end{array}$ & $\begin{array}{c}\text { Amino nitrogen } \\
\text { content [mg/g] }\end{array}$ & $\begin{array}{c}\text { Protein digestibility } \\
{[\%]}\end{array}$ & Amino acids \\
\hline Okara & 14.87 & 23.96 & 3.48 & 63.76 & - \\
Fermented okara (R.oligosporus) & 46.28 & 35.22 & 10.74 & 66.46 & increased, fluctuated \\
Fermented okara (A. oryzae) & 86.25 & 41.11 & 17.54 & 67.34 & increased, fluctuated \\
Tofu & 2.47 & - & - & - & - \\
Tempe & 24.64 & - & - & & \\
\hline
\end{tabular}

when okara was fermented by $A$. oryzae. The increase of essential amino acids in fermented okara by $R$. oligosporus was also identical, except for threonine. The fluctuation in the amino acid concentrations for fermented okara might be due to their utilizations for the metabolisms of both fungi (Kwon et al., 2010).

\subsection{Functional Comparison between unfermented, fermented okara, and other soy-based products.}

Solid-sate fermentation of okara with R. oligosporus was optimum with $1.04 \times 10^{-3} \mathrm{~g}_{\mathrm{DCW}} / \mathrm{g}_{\text {okara }}$ as initial concentration, substrate's water activity of 0.931 , and incubated for $5 \mathrm{~d}$. Whereas for A. Oryzae, $1.6 \times 10^{-3} \mathrm{~g}_{\mathrm{DCW}} / \mathrm{g}_{\text {okara }}$ was the optimum initial concentration with a substrate's water activity of 0.913 , and fermentation time of $4 \mathrm{~d}$. The antioxidant, protein content, amino nitrogen content and protein digestibility of fermented okara were found higher than unfermented one (Table 2). Additionally, the fermented okara was also found to have higher antioxidant activity than other soy-based products such as (commercial) tofu and tempe.

The particle size of okara was reduced down to $6.146 \times 10^{-1} \mu \mathrm{m}$ (see Table 1), whereas for tempe production, soybean is normally unmilled. Schmidt \& Furlong (2012) reported that substrates with smaller particles will result in a higher surface area leading a larger contact area between the fungus and the substrate, favoring its growth. Additionally, for the extracellular protease to work optimally a smaller particle size will enhance the access of the enzyme molecules to the protein located within the okara particles. Thereby, a higher degree of proteolysis will be pronounced that leads to the production of bioactive peptides (Guan et al., 2016; Yokomizo et al., 2002). About 815 ppm and 456 ppm of fermented okara (respectively by R. oligosporus and A. Oryzae), were equivalent with $1.0 \mathrm{ppm}$ of ascorbic acid in terms of antioxidant capacity.

\section{Conclusions}

Solid-state fermentation of okara either using R.oligosporus or A. oryzae could increase the antioxidant, protein content, amino nitrogen content and protein digestibility of okara. The initial fungal concentration and water activity were found to influence the successful okara fermentation, in terms of enhanced antioxidant capacity. Solid-sate fermentation of okara with $R$. oligosporus was optimum with $1.04 \times 10^{-3} \mathrm{~g}_{\mathrm{DCW}} / \mathrm{g}_{\text {okara }}$ as initial concentration, water activity of 0.931 , and incubated for $5 \mathrm{~d}$. The optimum conditions for A. Oryzae-based okara solid state fermentation were $1.6 \times 10^{-3} \mathrm{~g}_{\mathrm{DCW}} / \mathrm{g}_{\text {okara }}$ as the initial concentration, water activity of 0.913 , and fermentation time of $4 \mathrm{~d}$. The release of isoflavones-derived compounds and small molecular weight peptides and amino acids produced during the fermentation were considered to play role for the enhanced antioxidant activities of fermented okara using both fungi.

\section{Acknowledgements}

The authors would like to thank the Academic Melting Pot Program 2018 by King Mongkut's Institute of Technology, Ladkrabang, Thailand for the preparation of this manuscript.

\section{References}

Adebiyi, A. P., Adebiyi, A. O., Yamashita, J., Ogawa, T., \& Muramoto, K. (2009). Purification and characterization of antioxidative peptides derived from rice bran protein hydrolysates. European Food Research and Technology, 228(4), 553-563. http://dx.doi.org/10.1007/s00217008-0962-3.

Akeson, W. R., \& Stahmann, M. (1964). A pepsin pancreatin digest index of protein quality evaluation. The Journal of Nutrition, 83(3), 257-261. http://dx.doi.org/10.1093/jn/83.3.257. PMid:14191426.

Alen, Y., Suci, L. N., Suarmin, O., \& Rivai, H. (2017). Analysis of amino acids levels of freeze-dried termite queen Macrotermes gilvus Hagen. International Journal of Indigenuous Herbs and Drugs, 2(3), 1-5.

Almeida, C. C., Monteiro, M. L. G., Costa-Lima, B. R. C., Alvares, T. S., \& Conte-Junior, C. A. (2015). In vitro digestibility of commercial whey protein supplements. Lebensmittel-Wissenschaft + Technologie, 61(1), 7-11. http://dx.doi.org/10.1016/j.lwt.2014.11.038.

Association of Official Analytical Chemists - AOAC. (2005). Official Methods of Analysis of AOAC International (18th ed., William Horwitz \& George W. Latimer, editors). Gaithersburg: AOAC.

Barampama, Z., \& Simard, R. E. (1995). Effects of soaking, cooking and fermentation on composition, in-vitro starch digestibility and nutritive value of common beans. Plant Foods for Human Nutrition, 48(4), 349-365. http://dx.doi.org/10.1007/BF01088494. PMid:8882373.

Bourdichon, F., Casaregola, S., Farrokh, C., Frisvad, J. C., Gerds, M. L., Hammes, W. P., Harnett, J., Huys, G., Laulund, S., Ouwehand, A., Powell, I. B., Prajapati, J. B., Seto, Y., Ter Schure, E., Van Boven, A., Vankerckhoven, V., Zgoda, A., Tuijtelaars, S., \& Hansen, E. B. (2012). Food fermentations: microorganisms with technological beneficial use. International Journal of Food Microbiology, 154(3), 87-97. http:// dx.doi.org/10.1016/j.ijfoodmicro.2011.12.030. PMid:22257932.

Chan, W. M., \& Ma, C. Y. (1999). Acid modification of proteins from soymilk residue (okara). Food Research International, 32(2), 119-127. http://dx.doi.org/10.1016/S0963-9969(99)00064-2.

Chang, C. T., Hsu, C. K., Chou, S. T., Chen, Y. C., Huang, F. S., \& Chung, Y. C. (2009). Effect of fermentation time on the antioxidant activities of tempeh prepared from fermented soybean using Rhizopus 
oligosporus. International Journal of Food Science \& Technology, 44(4), 799-806. http://dx.doi.org/10.1111/j.1365-2621.2009.01907.x.

Chi, C. H., \& Cho, S. J. (2016). Improvement of bioactivity of soybean meal by solid-state fermentation with Bacillus amyloliquefaciens versus Lactobacillus spp. and Saccharomyces cerevisiae. LebensmittelWissenschaft + Technologie, 68, 619-625. http://dx.doi.org/10.1016/j. lwt.2015.12.002.

De Castro, R. J. S., \& Sato, H. H. (2014). Production and biochemical characterization of protease from Aspergillus oryzae: An evaluation of the physical-chemical parameters using agroindustrial wastes as supports. Biocatalysis and Agricultural Biotechnology, 3(3), 20-25. http://dx.doi.org/10.1016/j.bcab.2013.12.002.

Guan, Y., Wang, J., Wu, J., Wang, L., Rui, X., Xing, G., \& Dong, M. (2016). Enhancing the functional properties of soymilk residues (okara) by solid-state fermentation with Actinomucor elegans. CYTA: Journal of Food, 15(1), 1-9. http://dx.doi.org/10.1080/19476337.2016.1226955.

Hur, S. J., Lee, S. Y., Kim, Y. C., Choi, I., \& Kim, G. B. (2014). Effect of fermentation on the antioxidant activity in plant-based foods. Food Chemistry, 160, 346-356. http://dx.doi.org/10.1016/j. foodchem.2014.03.112. PMid:24799248.

Kamath, P., Subrahmanyam, V. M., Rao, J. V., \& Raj, P. V. (2010). Optimization of cultural conditions for protease production by a fungal species. Indian Journal of Pharmaceutical Sciences, 72(2), 161166. http://dx.doi.org/10.4103/0250-474X.65017. PMid:20838518.

Kasai, N., Murata, A., Inui, H., Sakamoto, T., \& Kahn, R. I. (2004). Enzymatic high digestion of soybean milk residue (okara). Journal of Agricultural and Food Chemistry, 52(18), 5709-5716. http://dx.doi. org/10.1021/jf035067v. PMid:15373413.

Krishna, C. (2005). Solid-state fermentation systems: an overview. Critical Reviews in Biotechnology, 25(1-2), 1-30. http://dx.doi. org/10.1080/07388550590925383. PMid:15999850.

Kwon, D. Y., Daily, J. W. 3rd, Kim, H. J., \& Park, S. (2010). Antidiabetic effects of fermented soybean products on type 2 diabetes. Nutrition Research, 30(1), 1-13. http://dx.doi.org/10.1016/j.nutres.2009.11.004. PMid:20116654.

Li, B., Qiao, M., \& Lu, F. (2012). Composition, nutrition, and utilization of okara (soybean residue). Food Reviews International, 28(3), 231252. http://dx.doi.org/10.1080/87559129.2011.595023.

Mateos-Aparicio, I., Mateos-Peinado, C., Jiménez-Escrig, A., \& Rupérez, P. (2010). Multifunctional antioxidant activity of polysaccharide fractions from the soybean byproduct okara. Carbohydrate Polymers, 82(2), 245-250. http://dx.doi.org/10.1016/j.carbpol.2010.04.020.

Morais, H. A., Silvestre, M. P. C., Silveira, J. N., Silva, A. C. S., Silva, V. D. M., \& Silva, M. R. (2013). Action of a pancreatin and an Aspergillus oryzae protease on whey proteins: correlation among the methods of analysis of the enzymatic hydrolysates. Brazilian Archives of Biology and Technology, 56(6), 985-995. http://dx.doi.org/10.1590/ S1516-89132013000600014.

Murakami, H., Asakawa, T., Terao, J., \& Matsushita, S. (1984). Antioxidative stability of tempeh and liberation of isoflavones by fermentation. Agricultural and Biological Chemistry, 48(12), 2971-2975. http:// dx.doi.org/10.1080/00021369.1984.10866635.

Nout, M. J. R., \& Kiers, J. L. (2005). Tempe fermentation, innovation and functionality: update into the third millenium. Journal of Applied Microbiology, 98(4), 789-805. http://dx.doi.org/10.1111/j.13652672.2004.02471.x. PMid:15752324.

Nuñez-Gaona, O., Saucedo-Castañeda, G., Alatorre-Rosas, R., \& Loera, O. (2010). Effect of moisture content and inoculum on the growth and conidia production by Beauveria bassiana on wheat bran. Brazilian Archives of Biology and Technology, 53(4), 771-777. http://dx.doi.org/10.1590/S1516-89132010000400004.

O'Keefe, S., Bianchi, L., \& Sharman, J. (2015). Soybean nutrition. SM Journal of Nutrition and Metabolism, 1(2), 1006.

O'Toole, D. K. (1999). Characteristics and use of okara, the soybean residue from soy milk production: a review. Journal of Agricultural and Food Chemistry, 47(2), 363-371. http://dx.doi.org/10.1021/ jf980754l. PMid:10563901.

Ohno, A., Ano, T., \& Shoda, M. (1996). Use of soybean curd residue, okara, for the solid state substrate in the production of a lipopeptide antibiotic, iturin A, by Bacillus subtilis NB22. Process Biochemistry, 31(8), 801-806. http://dx.doi.org/10.1016/S0032-9592(96)00034-9.

Prasad, D. S. R., \& Raju, K. J. (2013). Studies on the production of Neutral Protease by Rhizopus oligosporus NCIM 1215 using Lablab purpureus seed powder under solid state fermentation. Journal of Chemical, Biological and Physical Sciences, 3(4), 2772-2783.

Puri, S., Arora, M., \& Sarao, L. (2013). Production and optimization of amylase and glucoamylase using Aspergillus oryzae under solid state fermentation. International Journal of Research in Pure and Applied Microbiology, 3(3), 83-88.

Rashad, M. M., Mahmoud, A. E., Abdou, H. M., \& Nooman, M. U. (2011). Improvement of nutritional quality and antioxidant activities of yeast fermented soybean curd residue. African Journal of Biotechnology, 10(28), 5504-5513. http://dx.doi.org/10.5897/AJB10.1658.

Rauf, A., Irfan, M., Nadeem, M., \& Ahmed, I. (2010). Optimization of Growth Conditions for Acidic Protease Production from Rhizopus oligosporus through Solid State Fermentation of Sunflower Meal. International Journal of Agricultural and Biological Sciences, 1(1), 506-509.

Schiraldi, C., \& Rosa, M. (2014). Mesophilic organisms. In E. Drioli \& L. Giorno Encyclopedia of membranes (pp. 1-2). Heidelberg: Springer. https://doi.org/10.1007/978-3-642-40872-4_1610-2

Schmidt, C. G., \& Furlong, E. B. (2012). Effect of particle size and ammonium sulfate concentration on rice bran fermentation with the fungus Rhizopus oryzae. Bioresource Technology, 123, 36-41. http://dx.doi.org/10.1016/j.biortech.2012.07.081. PMid:22940295.

Sparringa, R. A., \& Owens, J. D. (1999). Glucosamine content of tempe mould, Rhizopus oligosporus. International Journal of Food Microbiology, 47(1-2), 153-157. http://dx.doi.org/10.1016/S01681605(99)00020-3. PMid:10357284.

Teng, D., Gao, M., Yang, Y., Liu, B., Tian, Z., \& Wang, J. (2012). Biomodification of soybean meal with Bacillus subtilis or Aspergillus oryzae. Biocatalysis and Agricultural Biotechnology, 1(1), 32-38. http://dx.doi.org/10.1016/j.bcab.2011.08.005.

Visessanguan, W., Benjakul, S., Potachareon, W., Panya, A., \& Riebroy, S. (2005). Accelerated proteolysis of soy proteins during fermentation of thua-nao inoculated with Bacillus subtilis. Journal of Food Biochemistry, 29(4), 349-366. http://dx.doi.org/10.1111/j.17454514.2005.00012.x.

Vong, W. C., Hua, X. Y., \& Liu, S. Q. (2018). Solid-state fermentation with Rhizopus oligosporus and Yarrowia lipolytica improved nutritional and flavour properties of okara. LWT - Food Science and Technology, 90, 316-322. https://doi.org/10.1016/j.lwt.2017.12.050

Wronkowska, M., Honke, J., \& Piskula Mariusz, K. (2015). Effect of solid-state fermentation with Rhizopus oligosporus on bioactive compounds and antioxidant capacity of raw and roasted buckwheat groats. Italian Journal of Food Science, 27(4), 424-431. 
Yokomizo, A., Takenaka, Y., \& Takenaka, T. (2002). Antioxidative Activity of Peptides Prepared from Okara Protein. Food Science and Technology Research, 8(4), 357-359. http://dx.doi.org/10.3136/fstr.8.357.

Yu, K. W., Lee, S. E., Choi, H. S., Suh, H. J., Ra, K. S., Choi, J. W., \& Hwang, J. H. (2012). Optimization for rice koji preparation using aspergillus oryzae CJCM-4 isolated from a korean traditional meju. Food Science and Biotechnology, 21(1), 129-135. http://dx.doi. org/10.1007/s10068-012-0016-2.
Zhang, S. T., Shi, Y., Zhang, S. L., Shang, W., Gao, X. Q., \& Wang, H. K. (2014). Whole soybean as probiotic lactic acid bacteria carrier food in solid-state fermentation. Food Control, 41(1), 1-6. http:// dx.doi.org/10.1016/j.foodcont.2013.12.026.

Zou, T., He, T. P., Li, H. B., Tang, H. W., \& Xia, E. Q. (2016). The structure-activity relationship of the antioxidant peptides from natural proteins. Molecules, 21(1), 1-14. http://dx.doi.org/10.3390/ molecules21010072. PMid:26771594. 